Milena Lipnická, Simoneta Babia Mariana Cabanová

Slovak Republik

\title{
Self-Evaluation of Future Teachers' Didactic Competencies
}

DOI: 10.15804/tner.2019.57.3.09

\begin{abstract}
The contribution presents partial results of research aimed to find out students' evaluation opinions of their own knowledge and experience for development of children's language and literary literacy in kindergartens and children's school clubs and to point out differences in self-evaluation, depending on the length and the form of the study. The research sample consisted of $98 \%$ of students of the full-time and part-time study programme of Pre-School and Elementary Pedagogy, 228 in total. An 11-item questionnaire of our own design was used in the research. In the items P5 - P11, students expressed their subjective evaluation opinion of their knowledge and experience on a five-point scale. Research results showed that students' self-evaluation of knowledge and experience in language and literary literacy depends on both the length and the form of their study ${ }^{1}$.
\end{abstract}

Key words: teachers, didactic competencies, language and literary literacy, kindergarten, children's school club

\section{Introduction - research background}

One of the research objectives of the project KEGA No. 013UMB-4/2016 "Creating curriculum related to language and literary literacy in the new accredited

1 The study is one of the outputs of the project KEGA No. 013UMB-4/2016 "Creating curriculum related to language and literary literacy in the new accredited Bachelor degree study" 
Bachelor degree study" is to recognize and assess didactic competencies of students of pre-school and elementary pedagogy Bachelor degree study. Achievement of the project objective will add to knowledge about students' process of learning didactic competencies to develop language and literary literacy in children in kindergartens and children"s school clubs.

Foreign research points to the importance of university students' language education (Renuga, Kanchana, Mala, 2015). Language education of future teachers and educational child-care staff should include diagnostics and self-evaluation of competencies. Barr et al. (2000) identify with it. They state that pre-service preparation of teachers should include also self-assessment processes. Leader-Janssen and Rankin-Erickson's (2013) research shows a correlation between acquired knowledge related to teaching reading and self-evaluation in pre-service teachers. They found out that study of theoretical disciplines connected with attendance at lectures and seminars has an improving influence on students' self-evaluation. Objectives of the project KEGA No. 013UMB-4/2016 pursue this purpose. In line with the reflective theoretical and practical model of teacher and educational child-care staff training (Rovňanová, Nemcová, 2017), project objectives focus also on students' self-evaluation related to didactic competencies, which is also the subject hereof.

Didactic competencies are teachers' cognitive, affective and motivational capacities to achieve successful results in children's learning. They allow teachers to carry out various teaching activities to fulfil educational objectives, thus implement generally recognized and innovative strategies, methods and forms of work in teaching (Petrovici, 2007).

In teacher preparation courses, students' initial didactic "equipment" is knowledge, skills, experience, opinions and attitudes. The European Commission's document Education and Training (2013) refers to teachers' didactic knowledge as "knowledge of the discipline". Students - future teachers learn scientific knowledge to modify contents of children's learning areas. They also acquire experience in teaching children both in simulated conditions of university classrooms and during teaching practice at schools. Cognitive processing of manifold knowledge and its evaluation allow students to reflect on instruction, their own competencies and relationships in the profession.

University instruction supports future teachers' didactic thinking by reflection on the processes of education and self-reflection on their own educational activity. Teachers' reflection on educational work includes self-evaluation.

Self-evaluation is one of the sources of students' self-development in the teaching profession. Kosová (2000, p. 52) wrote about self-evaluation that "based on it, 
an individual begins to lay down realistically achievable goals for oneself, makes effort to achieve them, is able to assess their achievement and lay down other ones." The educational benefit of self-evaluation is the authenticity of teachers" and pupils' assessment judgements of themselves. Future teachers' self-evaluation may be evoked by an outer assessment, a course or a situation, a certain circumstance, as well as an intentionally administered self-evaluation tool. In the present research, students' self-evaluation tool was a questionnaire.

In their self-evaluation, participants assess their knowledge also based on experience. According to Janík (2005), teachers' knowledge and experience are correlated. Teachers acquire experience through episodes (episodic knowledge). If it has come right a number of times in various situations of the educational process, they generalize it (experiential knowledge).

The importance of experience in learning competencies related to language and literary literacy was also pointed out by Ravid and Tolchinsky (2002). They studied the process of children learning language and literature contents from various aspects, depending on socio-cultural requirements of a "literate" person, or a person's literacy.

Literacy no longer means only the ability to read and write. It is a person's competence, "equipment" with capacities to actively learn, create and communicate in the mother tongue (as well as in a foreign language) in various situations for various purposes. Both in education and in everyday life, people learn manifold language and literary competencies and teachers are a part of it. To teach these competencies, teachers get prepared in the course of study subjects.

\section{Study subjects of language and literary literacy in the programme Pre-school and Elementary Pedagogy (Bc.)}

The Bachelor degree study of Pre-school and Elementary Pedagogy prepares future teachers for development of children's language and literary literacy. Students of the study programme 'Pre-school and Elementary Pedagogy' (Bc.) acquire didactic competencies to develop language and literary literacy in children in kindergartens and children's school clubs in the study subjects indicated in Table 1, during three years.

The basis of the future teachers' didactic competencies is acquisition of a number of competencies, the level of development of which is evaluated by the university teachers of the Matej Bel University Faculty of Education both during and at the end of instruction in individual terms. In connection with the objectives of the project 
Table 1. Study subjects for language and literary literacy in the Bachelor degree study programme 'Pre-school and Elementary Pedagogy' at the Matej Bel University

Faculty of Education

\begin{tabular}{|c|c|c|}
\hline 1. 1-st year & 2. 2-nd year & 3. 3-rd year \\
\hline $\begin{array}{l}\text { Basics of the Slovak language } \\
\text { (WT - C) }\end{array}$ & $\begin{array}{l}\text { Literature for children and } \\
\text { media } \\
(\mathrm{WT}-\mathrm{C})\end{array}$ & $\begin{array}{l}\text { Development of language } \\
\text { competencies at elementary } \\
\text { school } \\
\text { (WT-CO) }\end{array}$ \\
\hline \multirow[t]{2}{*}{$\begin{array}{l}\text { Language and literary lit- } \\
\text { eracy in kindergarten and } \\
\text { elementary school (ST - C) }\end{array}$} & $\begin{array}{l}\text { Development of language } \\
\text { competencies in kindergarten } \\
(\mathrm{WT}-\mathrm{CO})\end{array}$ & \\
\hline & $\begin{array}{l}\text { Creative dramatics in kinder- } \\
\text { garten and elementary school } \\
(\mathrm{ST}-\mathrm{CO})\end{array}$ & \\
\hline $\begin{array}{l}\text { Assistant practice in the ele- } \\
\text { mentary school 1-st class } \\
\text { (WT-C) }\end{array}$ & $\begin{array}{l}\text { Theory and practice of } \\
\text { pre-primary and primary } \\
\text { education } \\
\text { (WT-C) }\end{array}$ & $\begin{array}{l}\text { Children's school clubs and } \\
\text { educational programmes in } \\
\text { children's school clubs with } \\
\text { practice } \\
\text { (WT - C) }\end{array}$ \\
\hline
\end{tabular}

Note: WT - winter term, ST - summer term, C - compulsory subject, CO - compulsory optional subject

KEGA No. 013UMB-4/2016 "Creating curriculum related to language and literary literacy in the new accredited Bachelor degree study", we were interested whether there are differences in students' evaluation opinions (in self-evaluation) depending on the study length and form. The research was initiated by the need of the project team to know answers to some research questions that tag on research objectives.

\section{Methods of research}

The goal of the research was to find out evaluation opinions (self-evaluation) of students of the study programme 'Pre-school and Elementary Pedagogy' (Bc.) of their own knowledge and experience concerning the development of children's language and literary literacy in kindergartens and children's school clubs. The objective was: to find out differences in students' self-evaluations depending on the study length and form. The research problem was defined by means of the following questions: 
QUESTION 1. Do full-time and part-time students of the $3^{\text {rd }}$ year of Bachelor degree study evaluate their knowledge better than full-time and part-time students of the $1^{\text {st }}$ year? (questionnaire items 5 to 9 , finding out students' evaluation opinions of their own knowledge);

QUESTION 2. Do full-time and part-time students of the $3^{\text {rd }}$ year of Bachelor degree study evaluate their experience better than full-time and part-time students of the $1^{\text {st }}$ year? (questionnaire items 10 to 11 , finding out students' evaluation opinions of their own experience);

QUESTION 3. Do part-time students of the $1^{\text {st }}, 2^{\text {nd }}$ and $3^{\text {rd }}$ year of Bachelor degree study evaluate their knowledge better than full-time students of the $1^{\text {st }}, 2^{\text {nd }}$ and $3^{\text {rd }}$ year of study? (questionnaire items 5 to 9 , finding out students' evaluation opinions of their own knowledge);

QUESTION 4. Do part-time students of the $1^{\text {st }}, 2^{\text {nd }}$ and $3^{\text {rd }}$ year of study evaluate their experience better than full-time students of the $1^{\text {st }}, 2^{\text {nd }}$ and $3^{\text {rd }}$ year of study? (questionnaire items 10 to 11, finding out students' evaluation opinions on their own experience).

The research involved 228 students of the $1^{\text {st }}, 2^{\text {nd }}$ and $3^{\text {rd }}$ year of full-time and part-time study in the Bachelor degree programme Pre-school and Elementary Pedagogy. It was a convenience sample of respondents. Hence, there are limited possibilities to generalize the research results. Since representation of men in all three years of study was less than $1.8 \%$, this representation was not considered in the research. Detailed data on the research sample are presented in the table below.

Table 2. Research sample of Bachelor degree study students by years and forms of study

\begin{tabular}{|c|c|c|c|c|c|c|c|c|c|c|}
\hline \multirow{3}{*}{ 苞 } & \multirow{3}{*}{ 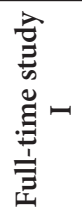 } & \multirow{3}{*}{ 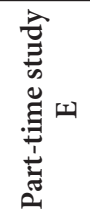 } & \multirow{3}{*}{ 퓽 } & \multicolumn{2}{|c|}{$\begin{array}{l}1-s t \\
\text { year }\end{array}$} & \multicolumn{2}{|c|}{$\begin{array}{l}\text { 2-nd } \\
\text { year }\end{array}$} & \multicolumn{2}{|c|}{$\begin{array}{l}\text { 3-rd } \\
\text { year }\end{array}$} & \multirow{3}{*}{ 퓽 } \\
\hline & & & & F-T & $\mathrm{P}-\mathrm{T}$ & F-T & P-T & F-T & P-T & \\
\hline & & & & 57 & 12 & 63 & 20 & 45 & 31 & \\
\hline Number & 165 & 63 & 228 & \multicolumn{2}{|c|}{69} & \multicolumn{2}{|c|}{83} & \multicolumn{2}{|c|}{76} & 228 \\
\hline
\end{tabular}

Legend to Table 1: FT - students of the full-time form of study, PT - students of the parttime form of study

The method of research was a questionnaire in printed form. It contained 11 items. They were designed based on teaching objectives in the development of students' didactic competencies in compulsory and compulsory optional subjects 
related to language and literary literacy (Tab. 1). The items 1 to 4 were of a demographic character. The items 5 to 11 focused on students' self-evaluation of their own knowledge and experience in development of children's language and literary literacy. The items used interval scales. Students evaluated their knowledge and experience by means of the interval scales as follows: 1 - excellent, 2 - very good, 3 - good, 4 - sufficient, 5 - insufficient. Items for evaluation of knowledge:

P5 - I evaluate my knowledge about theories of language development in children of pre-school age as $(1-2-3-4-5)$;

P6 - I evaluate my knowledge about theories of language and literary literacy development in children of pre-school age as $(1-2-3-4-5)$;

P7 - I evaluate my knowledge about reading and writing practice methods in primary education as $(1-2-3-4-5)$;

P8 - I evaluate my knowledge about methods of language and literary literacy development in children's school club as $(1-2-3-4-5)$;

P9 - I evaluate my knowledge about methods of children's language and literary literacy development in kindergarten as $(1-2-3-4-5)$.

Items for evaluation of experience:

P10 - I evaluate my reading experience in literature for children of pre-school and younger school age as $(1-2-3-4-5)$;

P11 - I evaluate my experience in educational activities and games developing children's language and communication skills as (1-2-3-4-5).

The questionnaire was administered during university instruction in language and literary literacy related subjects. Respondents filled in the questionnaire in 2017 , at the beginning of the winter term in the $38^{\text {th }}$ to $40^{\text {th }}$ week. Their evaluation opinions were processed and evaluated statistically.

\section{Research results}

Research data acquired by the questionnaire method were evaluated using descriptive and inductive statistics. The distribution of sample data values was normal, allowing use of parametric methods, namely the t-test. The measurement yielded the following interval data (Tab. 3).

Table 3. Statistical findings on the entire research sample

\begin{tabular}{cccc}
\hline Questionnaire item & Arithmetic mean & Standard deviation & Median \\
\hline P5 & 3.26 & 0.84 & 3 \\
\hline P6 & 3.22 & 0.79 & 3 \\
\hline
\end{tabular}




\begin{tabular}{cccc}
\hline Questionnaire item & Arithmetic mean & Standard deviation & Median \\
\hline P7 & 3.29 & 0.90 & 3 \\
\hline P8 & 3.44 & 0.94 & 3 \\
\hline P9 & 3.05 & 0.93 & 3 \\
\hline P10 & 2.95 & 1.01 & 3 \\
\hline P11 & 3.00 & 1.06 & 3 \\
\hline
\end{tabular}

\section{Knowledge and experience self-evaluation of students in the $1^{\text {st }}$ and $3^{\text {rd }}$ year of Bachelor degree study}

We were interested whether students of the $3^{\text {rd }}$ year of Bachelor degree study evaluated their knowledge better than students of the $1^{\text {st }}$ year (Question 1). Statistical evaluation of results showed that students of the $3^{\text {rd }}$ year evaluated their knowledge significantly better (significance at the level of $\mathrm{p} \leq 0.01$ ) than students of the $1^{\text {st }}$ year in the items P5, P6, P8, P9. Better evaluation of students in the $3^{\text {rd }}$ year was not statistically significant in the item P7. The P7 statement regards knowledge about reading and writing practice methods in primary education, and it was inserted in the questionnaire as a check item, to find out respondents' sincerity when filling in the questionnaire. Students are instructed on reading and writing practice methods in primary education only in the Master degree study programme.

Next, we investigated whether full-time and part-time students of the $3^{\text {rd }}$ year of Bachelor degree study evaluated their experience better than students of the $1^{\text {st }}$ year (Question 2). Statistical evaluation of results showed that students of the $3^{\text {rd }}$ year evaluated their experience significantly better (significance at the level of $\mathrm{p} \leq 0.01$ ) than students of the $1^{\text {st }}$ year in both items P10 and P11. The comparison of knowledge and experience self-evaluation of students in the $1^{\text {st }}$ and $3^{\text {rd }}$ year is presented in Table 4 below.

Table 4. Statistical data on knowledge and experience self-evaluation of full-time students in the 1-st and 3-rd year

\begin{tabular}{|c|c|c|c|c|c|c|c|c|}
\hline \multirow{2}{*}{ Questionnaire items } & \multicolumn{2}{|c|}{$\begin{array}{l}\text { Number of } \\
\text { respondents }\end{array}$} & \multicolumn{2}{|c|}{ Mean } & \multicolumn{2}{|c|}{$\begin{array}{l}\text { Standard } \\
\text { deviation }\end{array}$} & \multicolumn{2}{|c|}{ Student's t-test } \\
\hline & $\begin{array}{c}3^{\text {rd }} \\
\text { year }\end{array}$ & $\begin{array}{c}1^{\text {st }} \\
\text { year }\end{array}$ & $\begin{array}{c}3^{\text {rd }} \\
\text { year }\end{array}$ & $\begin{array}{c}1^{\text {st }} \\
\text { year }\end{array}$ & $\begin{array}{c}3^{\text {rd }} \\
\text { year }\end{array}$ & $\begin{array}{l}1^{\text {st }} \\
\text { year }\end{array}$ & $t$ & P \\
\hline $\begin{array}{l}\text { P } 5 \text { I evaluate my knowledge about } \\
\text { theories of language development } \\
\text { in children of pre-school age as }\end{array}$ & 76 & 69 & 2.9 & 3.4 & 0.75 & 0.93 & -3.46 & 0.0007 \\
\hline
\end{tabular}




\begin{tabular}{|c|c|c|c|c|c|c|c|c|}
\hline \multirow{2}{*}{ Questionnaire items } & \multicolumn{2}{|c|}{$\begin{array}{l}\text { Number of } \\
\text { respondents }\end{array}$} & \multicolumn{2}{|c|}{ Mean } & \multicolumn{2}{|c|}{$\begin{array}{l}\text { Standard } \\
\text { deviation }\end{array}$} & \multicolumn{2}{|c|}{ Student's t-tes } \\
\hline & $\begin{array}{c}3^{\text {rd }} \\
\text { year }\end{array}$ & $\begin{array}{c}1^{\text {st }} \\
\text { year }\end{array}$ & $\begin{array}{c}3^{\text {rd }} \\
\text { year }\end{array}$ & $\begin{array}{c}1^{\text {st }} \\
\text { year }\end{array}$ & $\begin{array}{l}3^{\text {rd }} \\
\text { year }\end{array}$ & $\begin{array}{c}1^{\text {st }} \\
\text { year }\end{array}$ & $\mathrm{t}$ & $\mathbf{P}$ \\
\hline $\begin{array}{l}\text { P } 6 \text { I evaluate my knowledge about } \\
\text { theories of language and literary } \\
\text { literacy development in children of } \\
\text { pre-school age as }\end{array}$ & 76 & 69 & 2.9 & 3.4 & 0.77 & 0.88 & -3.44 & 0.0008 \\
\hline $\begin{array}{l}\text { P } 7 \text { I evaluate my knowledge about } \\
\text { reading and writing practice meth- } \\
\text { ods in primary education as }\end{array}$ & 76 & 69 & 3.1 & 3.4 & 0.82 & 1.10 & -1.70 & 0.0898 \\
\hline $\begin{array}{l}\text { P } 8 \text { I evaluate my knowledge about } \\
\text { methods of language and literary } \\
\text { literacy development of children in } \\
\text { children's school club as }\end{array}$ & 76 & 69 & 3.1 & 3.6 & 0.89 & 1.01 & -2.67 & 0.0085 \\
\hline $\begin{array}{l}\text { P } 9 \text { I evaluate my knowledge about } \\
\text { methods of children's language and } \\
\text { literary literacy development in } \\
\text { kindergarten as }\end{array}$ & 76 & 69 & 2.6 & 3.3 & 0.85 & 1.10 & -3.98 & 0.0001 \\
\hline $\begin{array}{l}\text { P } 10 \text { I evaluate my reading expe- } \\
\text { rience in literature for children of } \\
\text { pre-school and younger school } \\
\text { age as }\end{array}$ & 76 & 69 & 2.5 & 3.0 & 0.81 & 0.96 & -3.59 & 0.0005 \\
\hline $\begin{array}{l}\text { P } 11 \text { I evaluate my experience in } \\
\text { educational activities and games } \\
\text { developing children's language and } \\
\text { communication skills as }\end{array}$ & 76 & 69 & 2.6 & 3.2 & 0.88 & 1.16 & -3.19 & 0.0018 \\
\hline
\end{tabular}

Legend to Tab. 4. Evaluation scale: 1 - excellent, 2 - very good, 3 - good, 4 - sufficient, 5 - insufficient.

\section{Knowledge and experience self-evaluation of students in full-time and part-time Bachelor degree study}

We were interested whether part-time students of the $1^{\text {st }}, 2^{\text {nd }}$ and $3^{\text {rd }}$ year evaluated their knowledge better than full-time students of the $1^{\text {st }}, 2$-nd and $3^{\text {rd }}$ year of Bachelor degree study (Question 3). Both full-time and part-time students study by curriculum in the joint study programme. Full-time students have daily contact periods with their teachers during their university instruction. Part-time students in the Bachelor study programme study mostly while employed, in the form of Friday and block instruction. Nevertheless, students of three years of part-time study evaluated their own knowledge significantly better than students of three 
years of full-time study (significance at the level of $p \leq 0.01$ ). Again, the significant difference was not confirmed only in the item P7. We investigated whether parttime students of Bachelor degree study evaluated their own experience better than full-time students of Bachelor degree study (Question 4). Students of three years of the part-time study form also evaluated their own experience (items P10 and P11) significantly better than students of the full-time study form. The comparison of knowledge and experience self-evaluation of students in the $1^{\text {st }}, 2^{\text {nd }}$ and $3^{\text {rd }}$ year of the full-time and part-time study forms is presented in Table 5 below.

Table 5. Statistical data on knowledge and experience self-evaluation of full-time and part-time students

\begin{tabular}{|c|c|c|c|c|c|}
\hline \multirow[b]{2}{*}{ Number and wording of the questionnaire item } & \multirow{2}{*}{$\begin{array}{l}\text { Number of } \\
\text { Respond- } \\
\text { ents }\end{array}$} & \multicolumn{2}{|l|}{ Mean } & \multicolumn{2}{|c|}{ Student's t - test } \\
\hline & & $\begin{array}{l}\text { Full- } \\
\text { time }\end{array}$ & $\begin{array}{l}\text { Part- } \\
\text { time }\end{array}$ & $\mathrm{t}$ & $\mathrm{p}$ \\
\hline $\begin{array}{l}\text { P } 5 \text { I evaluate my knowledge about theories of lan- } \\
\text { guage development in children of pre-school age as }\end{array}$ & 228 & 3.4 & 3.0 & 3.04 & 0.0026 \\
\hline $\begin{array}{l}\text { P } 6 \text { I evaluate my knowledge about theories of lan- } \\
\text { guage and literary literacy development in children } \\
\text { of pre-school age as }\end{array}$ & 228 & 3.3 & 3.0 & 2.48 & 0.0138 \\
\hline $\begin{array}{l}\text { P } 7 \text { I evaluate my knowledge about reading and } \\
\text { writing practice methods in primary education as }\end{array}$ & 228 & 3.3 & 3.1 & 1.64 & 0.1018 \\
\hline $\begin{array}{l}\text { P } 8 \text { I evaluate my knowledge about methods of lan- } \\
\text { guage and literary literacy development of children } \\
\text { in children's school club as }\end{array}$ & 228 & 3.6 & 3.0 & 4.57 & 0.0000 \\
\hline $\begin{array}{l}\text { P } 9 \text { I evaluate my knowledge about methods of } \\
\text { children's language and literary literacy develop- } \\
\text { ment in kindergarten as }\end{array}$ & 228 & 3.2 & 2.7 & 3.41 & 0.0008 \\
\hline $\begin{array}{l}\text { P } 10 \text { I evaluate my reading experience in literature } \\
\text { for children of pre-school and younger school age } \\
\text { as }\end{array}$ & 228 & 3.1 & 2.6 & 3.24 & 0.0012 \\
\hline $\begin{array}{l}\text { P } 11 \text { I evaluate my experience in educational activ- } \\
\text { ities and games developing children's language and } \\
\text { communication skills as }\end{array}$ & 228 & 3.1 & 2.7 & 2.98 & 0.0032 \\
\hline
\end{tabular}

Legend to Tab. 5: Evaluation scale 1 - excellent, 2 - very good, 3 - good, 4 - sufficient, 5 - insufficient.

Although the median is 3 in all self-evaluation items, there are statistically significant differences in self-evaluation between full-time students of the $1^{\text {st }}$ and the $3^{\text {rd }}$ year, and between full-time and part-time students of the $1^{\text {st }}, 2^{\text {nd }}$ and $3^{\text {rd }}$ year of Bachelor study. It means that students not inclined to a median value ticked extreme values in their self-evaluation. 


\section{Discussion}

Students in the $3^{\text {rd }}$ year of Bachelor degree study evaluated their own didactic competencies better than students in the $1^{\text {st }}$ year. The third-year students were more confident about their knowledge and experience. Better self-evaluation did not show as statistically significant in students of the $2^{\text {nd }}$ year against students of the $1^{\text {st }}$ year. After two years of Bachelor degree study, they were still not confident about their didactic competencies. Naturally, such results were expected, but not with absolute certainty. We were also concerned whether students of the $3^{\text {rd }}$ year would really demonstrate in their answers a better evaluation of knowledge and experience which we consider as their personal profit from the study in the development of their own didactic competencies. This finding is deemed to be objective mainly because they passed subjects related to language and literary literacy in the Bachelor degree study. A possible reason for better self-evaluation of the third-year students was also them having passed teaching practice in the 1 -st and $2^{\text {nd }}$ year of study (Tab. 1; Line 5). The fact that students of the $3^{\text {rd }}$ year in comparison with the students of the $1^{\text {st }}$ year did not evaluate their knowledge and experience in methods of elementary reading and writing practice significantly better indicates the sincerity of answers in questionnaires. This issue is the subject of Master degree study in primary education. Thus, the check item had its meaning in the questionnaire.

Based on the statistical findings, we can state that the didactic competencies of students of pre-school and elementary education, related to the development of children's language and literary literacy, improve gradually. It means that it is a gradual process of becoming kindergarten teachers and educational child-care professionals for children's school clubs.

Students of the part-time study form evaluated their knowledge and experience related to language and literary literacy significantly better than students of the full-time study form. This did not hold only for knowledge of methods of reading and writing practice in primary education (Tab. 5; Line 4). Part-time students, in comparison with full-time students, had more opportunities to work with children in the field. A majority of them had educational experience of more years. Better self-evaluation of knowledge and experience in part-time students against full-time students indicates the importance of practical activities in the teaching profession. Some students of part-time Bachelor degree study were employed in the school system; some had their own children attending kindergartens or children's school clubs. That could also influence their self-evaluation. They could acquire knowledge and experience about children's language and literary literacy 
in educational practice. In addition, part-time students, as well as full-time students, passed compulsory subjects connected with practice (Tab. 1; Line 5). Better self-evaluation of didactic competencies by part-time students could be caused also by other factors, for instance, insufficient feedback from university teachers due to a lower number of contact periods in instruction. Part-time students do not have so many consultations with teachers as full-time students; sometimes none. They do not have so many opportunities for discussions and a critical feedback in preparation and performance of educational activities for the development of children's language and literary literacy. This could also be the reason why parttime students were less critical of their own didactic competencies and evaluated their knowledge and experience better.

When university teachers have a tool box of didactic tools, strategies and teaching techniques, they can have a tremendous impact on development of students' didactic competencies. Practical experience allows students to carry out and improve their educational skills (Berenato, 2017).

\section{Conclusion}

We are aware of the fact that our research has both its benefits and limits. The major limit of the research was the method used. Students could not evaluate all their knowledge and experience. They had no possibility to describe and explain them in detail. Interviews with students would provide more precise information, although from a smaller number of students. There were only 11 items in the questionnaire, which reduced its reliability. The research was limited also by its size, sample availability and local character. Our research vision is to increase the sample by graduates active in practice. In line with the findings of Leader-Janssen and Rankin-Erickson (2013), our research results confirmed that development of future teachers and educational child-care staff is a gradual process. The length of study, thus passing the subjects taught improves self-evaluation of didactic competencies in students of the teaching profession. Another important issue is theoretical, didactic and methodological preparation aimed at the harmonious development of students' theoretical knowledge and practical experience spread in full-time study over three years. The above discussed findings of our research revealed possible shortcomings in the university teachers' feedback given to parttime students on the development of their knowledge and experience. It should be improved by an extension of the part-time Bachelor study programme to four years and more contact periods and consultations, reflections with teachers of the 
subjects. However, we consider the research results to be of benefit for the development of the curriculum related to language and literary literacy. The investigation is meaningful also for the follow-up research projects and for the improvement of the diagnostic process of students' competencies in their own educational practice.

\section{References:}

Barr, R., Watts-Taffe, S., Yokota, J., Ventura, M., \& Caputi, V. (2000). Preparing teachers to teach literacy: Rethinking preservice literacy education. Journal of Literacy Research, 32(4), 463-470.

Berenato, C. (2017) Early literacy teacher preparation: multisensory structured language education. Proceedings include at ICERI 2017conference, p. 2330. Sevilla: IATED.

European Commission/Education and Training (2013). Supporting teacher competence development. Retrieved 2/20/2018, from http://ec.europa.eu/dgs/education_culture/ repository/education/policy/school/doc/teachercomp_en.pdf

Janík, T. (2005). Znalost jako klíčvá kategorie učitelského vzdělávání. (Knowledge as the key category of teacher training), Brno: Paido.

Kosová, B. (2000). Rozvoj osobnosti žiaka. Banská Bystrica: Pedagogická fakulta Univerzity Mateja Bela. (Development of pupil personality. Banská Bystrica: Faculty of Education, Matej Bel University)

Leader-Janssen, E.M., \& Rankin-Erickson, J.L. (2013). Preservice Teachers' Content Knowledge and Self-Efficacy for Teaching Reading. Literacy Research and Instruction, 52(3), 204-229.

Petrovici, C. (2007). Teacher and career education competences of didactic profession - taxonomic models. Retrieved 2/20/2018, from http://www.researchgate.net/publication/255170572_TEACHER_AND_CAREER_EDUCATION:COMPETENCES_ OFDIDACTIC_PROFESSION_TAXONOMIC_MODELS

Ravid, D., \& Tolchinsky, L. (2002). Developing linguistic literacy: a comprehensive model. J. Child Lang, 29, 417-447.

Renuga, M., \& Kanchana Mala, B. (2015) Students' Perceptions of Themselves as Readers and the Concept of Reading. The New Educational Review, 41, (3), 86-97.

Rovňanová, L., \& Nemcová, L. (2017). Integration of theoretical and Practical undergraduate training in the Processes of Developing student teachers' Professional Competences. The New Educational Review, 47, (1), 176-186. 